\title{
THE OPTIMIZING OF STUDENT'S MATHEMATICAL THINKING SKILLS THROUGH MATEMATIKA NALARIA REALISTIK IN MATHEMATICS OLYMPIAD TRAINING AT MADRASAH IBTIDAIYAH
}

\author{
Rusdin $^{1}$, Rusli $^{2}$ \\ Sekolah Tinggi Agama Islam Negeri Sorong, Indonesia ${ }^{1}$, SUPM Negeri Sorong, \\ Indonesia $^{2}$ \\ E-mail: rusdin@stainsorong.ac.id ${ }^{1}$, rusliazis.ra@gmail.com ${ }^{2}$
}

DOI: $\underline{\text { 10.14421/al-bidayah.v12i1.305 }}$

\begin{abstract}
This study aimed to select and identify Madrasah Ibtidaiyah (MI) Students' at Sorong City having mathematical Olympiad skills using Matematika Nalaria Realistik (MNR) Learning Model. Through this model, it will be analysed students' mathematical thinking skills, including mathematical comprehension skills, mathematical communication skills, and mathematical reasoning skills. The subject of this research was 33 students in $5^{\text {th }}$ grade and two students in $6^{\text {th }}$ grade at MI Sains Al-Hidayah Sorong City. This study applied the design research method with three phases, namely, preliminary design, teaching experiment, and retrospective analysis. Data on students' mathematical thinking skills were obtained through pre-test and post-test using descriptive analysis in each phase. Results of this study in the preliminary design involving 35 students were obtained pre-test (1) average was 9,74; (2) standard deviation was 15.72. The results of the teaching experiment phase were obtained post-test (1) average was 13,57; (2) standard deviation was 13,75; and (3) an increase of 39,32\%. The results of the retrospective analysis involving 7 students were obtained pre-test (1) average was 38,28; (2) standard deviation was 23,09. In the post-test was obtained (1) average was 72,28; (2) standard deviation was 9,81; and (3) an increase of 88,77\%. Thus MNR model contributed significantly to improve students' mathematical thinking skills. From 7 students participating in the final phase, three students had good skills, and four students had moderate skills.
\end{abstract}

Keywords: mathematical thinking skills; reasoning; olympiad

\section{INTRODUCTION}

Education at the elementary school or Madrasah Ibtidaiyah (MI) is a basis as well as a foundation for the next level of education. ${ }^{1}$ Quality improvement at this level is a significant concern for the government and education providers. ${ }^{2}$ The indicators of quality improvement at an educational level are the increase in students' abilities, both regarding lesson's substances, creativity development, reasoning, attitudes, and students'

1 Directorate General of Primary and Secondary Education, Petunjuk Teknis Olimpiade Sains Nasional Sekolah Dasar Tahun 2018 (Jakarta, Indonesia: Directorate General of Primary and Secondary Education Ministry of Education and Culture, 2018), 1.

${ }^{2}$ Website Manager of MoEC, "Tingkatkan Mutu Pendidikan Melalui 4 Hal Ini," Kementerian Pendidikan dan Kebudayaan, August https://www.kemdikbud.go.id/main/blog/2018/08/tingkatkan-mutu-pendidikan-melalui-empat-hal-ini. 
characteristics. ${ }^{3}$ The most crucial skill that students need to gain at present and in the future is the ability to determine for themselves what they should do. ${ }^{4}$

The program conducted by the government to improve the quality of education, particularly in creative development, reasoning, and critical thinking skills, is through National Science Olympiad and Madrasah Science Competition (or called KSM, in Indonesia). Olympiad training is a program attempting to detect and produce students having talents and abilities in both science and other specialized skills. Branches of the Olympiad could be in the form of sports, art skills, or science. The focus of this research is the science olympiad, namely mathematics. Both internationally and nationally, mathematics olympiad is conducted from elementary level to higher education. In Indonesia, for the competition carried out by the government, the selection process is started from districts or city level, provincial level, to the national level.

In this research, mathematical thinking skills' definition refers to the meaning of Kaye Stacey stating that mathematical thinking skills are a set of abilities including mathematical comprehension skills, mathematical communication skills, mathematical connection skills, and mathematical reasoning skills. ${ }^{5}$ Critical thinking in madrasah ibtidaiyah was able to grow by implementing multi-method learning and classroom management. ${ }^{6}$ These elements have been included in the Matematika Nalaria Realistik (MNR) learning model.

In mathematics, reason and thought have an authentic role as this subject is very concerned with procedures with strong reasoning patterns in problem-solving. MNR is a breakthrough in learning mathematics. This model more emphasizes on the use of reasoning in comprehending mathematics. ${ }^{7}$ MNR teaches the students to analyze the

${ }^{3}$ Jessie Brown and Martin Kurzweil, Instructional Quality, Student Outcomes, and Institutional Finances (Washington, DC: American Council on Education, 2018), 3-7, https://www.acenet.edu/Documents/Instructional-Quality-Student-Outcomes-and-InstitutionalFinances.pdf.

4 Masami Isoda and Shigeo Katagiri, Mathematical Thingking: How to Develop It in the Classroom (Singapore: World Scientific, 2012), 31.

${ }^{5}$ Kaye Stacey, What Is Mathematical Thinking and Why Is It Important? (Melbourne: University of Melbourne, 2006); Kaye Stacey, "What Is Mathematical Thinking and Why Is It Important," accessed May 19, 2020, https://www.academia.edu/34010244/What_is_mathematical_thinking_and_why_is_it_important.

${ }^{6}$ Andi Prastowo et al., "Pembelajaran Keterampilan Berpikir Kritis: Studi Kasus Di MIM Ngipik Dan MIM Dondong Kulonprogo," Edukasia: Jurnal Penelitian Pendidikan Islam 13, no. 2 (May 27, 2019): 283, https://doi.org/10.21043/edukasia.v13i2.3525.

${ }^{7}$ Tim Klinik Pendidikan MIPA, Pintar Matematika Nalaria Realistik (Bogor: Klinik Pendidikan MIPA, 2012), 2. 
problems, draw conclusions, and solve the problems with various problem-solving methods.

This study implemented the MNR learning model at Madrasah Ibtidaiyah at Sorong City and its impacts on MI's talented students in mathematics Olympiad. Thus, the research aim is to improve mathematical thinking skills. Besides, this research benefits is a tool to select and bring talented students who will represent West Papua Province in mathematics Olympiad and national mathematics competition. The other reason is in the last four years, representation from West Papua did not get medals in the National Science Olympiad and National Science Competition. Moreover, it was expected from this research, and it will be produced by students who will represent Indonesia at the International Mathematics Competition. This study conducted at MI Sains Al-Hidayah Sorong City. This school is a quite representative to represent MI at Sorong City West Papua. Based on the data obtained, this school has represented West Papua Province at National Science Olympiad in 2014 ( silver medal in Natural Science , KSM), 2015 and 2016 ( bronze medal in Natural Science KSM), and national participant in National Science Olympiad in 2016, KSM in 2017, and National Science Olympiad in $2018 .^{8}$

\section{Mathematical Thinking Skills}

Mathematical thinking can be learned by elementary school teachers who teach students mathematical thinking. ${ }^{9}$ Mathematical thinking skills refer to a set of abilities, including mathematical comprehension skills, mathematical communication skills, mathematical connection skills, and mathematical reasoning skills. ${ }^{10}$ The definition of mathematical comprehension skills is a measure of the quality and quantity of the relationship between ideas and the ideas already exists. ${ }^{11}$ Comprehension abilities is an ability to connect the existing ideas to construct new ideas. According to John Van de

8 Director of Directorate of Primary and Secondary Education of MoEC, "Decree of the Directorate of Primary and Secondary Education of the Ministry of Education and Culture Regarding Data on Participants of the 2018 National Science Olympiad" (the Directorate of Primary and Secondary Education of the Ministry of Education and Culture, 2018).

9 Masami Isoda and Shigeo Katagiri. Mathematical Thingking: How to Develop it in the classroom. Singapore: Word Scientific, 2012. 23.

${ }^{10}$ E. Susanti and Hartono, "An Analysis Mathematical Problem Solving and Mathematical Critical Thinking Skills of Junior High School Students," Journal of Physics: Conference Series 1320 (October 2019): 012071, https://doi.org/10.1088/1742-6596/1320/1/012071.

11 John A. Van de Walle and Jennifer M. Bay-Williams, Elementary and Middle School Mathematics: Teaching Developmentally (7th Edition) (USA: Pearson Education, 2010), 26. 
Walle, comprehension abilities could be classified into two skills, which are relational ability and instrumental ability. Polya categorised comprehension ability into four parts, namely mechanical, inductive, rational, and intuitive. ${ }^{12}$

Mathematical comprehension skills in this study were the ability to absorb and understand mathematical ideas ${ }^{13}$ with indicators: (1) identifying and making examples; (2) translating and interpreting symbols' meaning, tables, diagrams, graphs, and figures; (3) understanding and applying ideas; (4) making estimations.

Mathematical communication skills are the ability of the student to convey something he/she knows in the form of mathematical ideas, both orally and written, as well as the ability to accept and understand other people's ideas carefully, critically, and evaluatively to sharpen the understanding. According to NCTM, indicators of mathematical communication skills could be seen from: (1) the ability to express mathematical ideas through oral, written, and demonstrating and visualizing them; (2) the ability to understand, interpret, and evaluate the mathematical ideas both in the form orally and other visual forms; (3) the ability to use mathematical terms, mathematical notations and its structures to present ideas, describe the relationships, and situations models. ${ }^{14}$

\section{Mathematical Connection Skills}

A mathematical connection skill refers to an ability to associate mathematical concepts and associate them with other fields. ${ }^{15}$ This ability is one of the highest mathematical thinking abilities. Indicators of mathematical connection skills are formulated as follow: (1) looking for relationships of various concepts' representation and procedure; (2) understanding the relationship between mathematical topics, and

${ }^{12}$ G. Polya, How to Solve It: A New Aspect of Mathematical Method (Garden City, New York: Doubleday \& Company Inc., 1985), https://math.hawaii.edu/home/pdf/putnam/PolyaHowToSolveIt.pdf.

${ }^{13}$ E. Rosdianwinata, R. Rifa'i, and Anton Nasrullah, "Implementation of Peer Tutor Learning in Improving Students' Mathematical Understanding Ability," Journal of Physics: Conference Series 1315 (October 2019): 012027, https://doi.org/10.1088/1742-6596/1315/1/012027.

14 National Council of Teachers of Mathematics (NCTM), Principles and Standards for School Mathematics (Reston: NTCM, 2000).

15 D. S. Ayunani, Mardiyana, and D. Indriati, "Analyzing Mathematical Connection Skill in Solving a Contextual Problem," Journal of Physics: Conference Series 1511 (April 2020): 012095, https://doi.org/10.1088/1742-6596/1511/1/012095. 
among the mathematical problems and other fields; (3) making a reason for each step of mathematical work. ${ }^{16}$

\section{Mathematical Reasoning Skills}

The reasoning is a thinking process carried out in the way of concluding. ${ }^{17}$ Mathematical reasoning is analytical ability, generalizing, synthesizing or integrating, and giving the right reasons to solve non-routine problems. ${ }^{18}$ Indicators of mathematical reasoning skills are as follows: (1) drawing logical conclusions; (2) providing explanations with the models, facts, features, and relationships; (3) predicting the answers and solution's process; (4) using patterns and relationships to analyze situations or making analogies and generalizations; (5) compiling and testing the conjectures; (6) making counterexamples; (7) making valid arguments; (8) arranging direct and indirect proofs, and mathematical induction. ${ }^{19}$

\section{Matematika Nalaria Realistik}

Matematika Nalaria Realistik (MNR) is an innovation in learning mathematics. ${ }^{20}$ MNR more emphasizes on the use of reasoning in comprehending mathematics. ${ }^{21}$ With MNR, students are taught to analyze the problems, draw conclusions, and to solve that problems using various methods in problem-solving, which is based on logic. ${ }^{22}$ The characteristics of MNR more emphasize on the use of reasoning in understanding

${ }^{16}$ Sarkam, I. Sujadi, and S. Subanti, "Mathematical Connections Ability in Solving Trigonometry Problems Based on Logical-Mathematical Intelligence Level," Journal of Physics: Conference Series 1188 (March 2019): 012022, https://doi.org/10.1088/1742-6596/1188/1/012022; E. Astari and Marsigit, "Mathematical Connections Process for Elementary School Students in Problem Solving of Statistics," Journal of Physics: Conference Series 1280 (November 2019): 042008, https://doi.org/10.1088/17426596/1280/4/042008.

${ }^{17}$ S. Y. Wulandari and D. U. Wutsqa, "A Study of Junior High School Students Reasoning Skill in Mathematics," Journal of Physics: Conference Series 1320 (October 2019): 012059, https://doi.org/10.1088/1742-6596/1320/1/012059.

18 G. I. Ratnasari and A. M. Abadi, "Investigating Mathematical Literacy, Mathematical Reasoning Skill, and Self Esteem of a Public High School," Journal of Physics: Conference Series 1097 (September 2018): 012096, https://doi.org/10.1088/1742-6596/1097/1/012096.

${ }^{19}$ N. A. P. Yaman and Jailani, "The Effect of Changes in Mathematics Curriculum in Improving Students' Reasoning Skills and Mathematical Problem Solving," Journal of Physics: Conference Series 1320 (October 2019): 012108, https://doi.org/10.1088/1742-6596/1320/1/012108.

20 Rusdin Rusdin, "Meningkatkan Kemampuan Berpikir Matematis Siswa Melalui Model Pembelajaran Matematika Nalaria Realistik Pada Madrasah Ibtidaiyah Di Kota Sorong," Al-Riwayah: Jurnal Kependidikan 11, no. 2 (September 2, 2019): 283-96, https://ejurnal.iainsorong.ac.id/index.php/Al-Riwayah/article/download/196/193.

${ }^{21}$ Mela Vega Rinata, "Penerapan Metode Matematika Nalaria Realistik Di Klinik Pendidikan MIPA Cabang 1 Surabaya," Jurnal Penelitian Pendidikan Guru Sekolah Dasar 7, no. 1 (January 24, 2019), https://jurnalmahasiswa.unesa.ac.id/index.php/jurnal-penelitian-pgsd/article/view/26884.

${ }^{22}$ Tim Klinik Pendidikan MIPA, Pintar Matematika Nalaria Realistik Edisi Revisi (Bogor: Klinik Pendidikan MIPA, 2017), 2 
mathematics as well as improving reasoning skills and improving problem-solving skills. Teaching syntax of MNR as follows: (1) posing the real problems; (2) Understanding the concept; (3) reasoning and communication; (4) problem solving; (5) applying in daily life; (6) mathematical exploration; and (7) Mathematical games.

\section{RESEARCH METHODS}

This study is a design research that is a research method aiming to develop Local Instruction Theory (LIT) by collaborating among researchers and teachers to improve the quality of learning. ${ }^{23}$ LIT is a theory of learning process describing learning trajectory on a particular topic with a set of supporting activities. Design research consists of three phases, namely preliminary design, teaching experiment, and retrospective analysis. ${ }^{24}$

This study was conducted for two months at MI Sains Al Hidayah Sorong city, starting from July 2018 to September 2018. Subject of this study was 35 students consisting of 33 students Grade VA and two students Grade VIA of MI Sains AL Hidayah academic year 2018/2019.

The data collection process was conducted through tests, namely pre-test and post-test. Besides, the data collection process was carried out in the form of written data and documentation of students' learning activities and students' answers. Descriptive statistical analysis was conducted to examine the central tendency and measure of dispersion about sample characteristics and indicators of the research variables. Data analysis was carried out to compare the results of the pre-test at the preliminary design phase with the results of the post-test at the retrospective analysis phase.

\section{RESULT AND DISCUSSION}

This research generally is divided into three stages, which are preliminary design, teaching experiment, and pilot experiment summarised in design experiment and retrospective analysis.

23 Koeno Gravemeijer and Dolly van Eerde, "Design Research as a Means for Building a Knowledge Base for Teachers and Teaching in Mathematics Education," The Elementary School Journal 109, no. 5 (May 1, 2009): 510-24, https://doi.org/10.1086/596999.

${ }^{24}$ Rully C.I. Prahmana, Design Research (Teori Dan Implementasinya: Suatu Pengantar) (Depok: Rajawali Perss, 2017). 
At the preliminary design, the initial ideas were implemented into the syntax of the MNR learning model to improve mathematical thinking skills, which is then used as a reference to select the talented students in the math Olympiad. This activity was done by reviewing the literature, making observations at MI Sains Al Hidayah Sorong city, having discussions with teachers and the headmaster, gaining data related to students' achievements and related documents, and ending up by seeing students' initial abilities through a pre-test.

Data and documents about students' achievements were presented in table 1, and the results of the pre-test were presented in table 2. Initial information obtained was used as a basic foundation at the teaching experiment stage. Table 1 shows awards and achievements in mathematics and science achieved by MI Sains Al-Hidayah Sorong City from 2014 to 2018.

Table 1

List of Achievement in OSN and KSM MI Sains Al Hidayah Kota Sorong ${ }^{25}$

\begin{tabular}{|c|c|c|c|c|}
\hline No. & Achievement & Year & Level & Medal \\
\hline 1. & $1^{\text {st }}$ winner in KSM Matematika & 2014 & Sorong city & \\
\hline 2. & $1^{\text {st }}$ winner in KSM Sains & 2014 & Sorong city & \\
\hline 3. & $1^{\text {st }}$ winner in KSM Sains & 2014 & West Papua & \\
\hline 4. & KSM Bidang Sains (IPA) & 2014 & National & Silver \\
\hline 5. & KSM Bidang Sains (IPA) & 2015 & National & Bronze \\
\hline 6. & $1^{\text {st }}$ winner in KSM Matematika & 2016 & Sorong city & \\
\hline 7. & KSM Bidang Sains (IPA) & 2016 & National & Bronze \\
\hline 8. & OSN Bidang IPA & 2017 & West Papua & \\
\hline 9. & OSN Matematika & 2017 & West Papua & \\
\hline 10. & OSN Bidang IPA & 2017 & National & \\
\hline 11. & OSN Matematika & 2017 & National & \\
\hline 12. & KSM Matematika & 2017 & West Papua & \\
\hline 13. & KSM Sains (IPA) & 2017 & West Papua & \\
\hline 14. & $1^{\text {st }}$ rank in OSN IPA & 2018 & West Papua & \\
\hline 15. & $1^{\text {st }}$ rank in OSN Matematika & 2018 & West Papua & \\
\hline 16. & OSN IPA & 2018 & National & \\
\hline 17. & OSN Matematika & 2018 & National & \\
\hline 18. & $1^{\text {st }}$ rank in KSM Sains (IPA) & 2018 & West Papua & \\
\hline 19. & $1^{\text {st }}$ rank in KSM Matematika & 2018 & West Papua & \\
\hline 20. & KSM IPA & 2018 & National & \\
\hline 21. & KSM Matematika & 2018 & National & \\
\hline
\end{tabular}

${ }^{25}$ Profile of MI (Islamic Elementary School) Sains Al Hidayah, 2018 
From Table 1, it is clear that MI Sains Al-Hidayah has represented Sorong city at the provincial level 5 times, namely in 2014, 2015, 2016, 2017, and 2018 in KSM and succeeded to the national level by achieving 2 bronze medals and 1 silver medal. In contrast, in KSM Matematika, it has not achieved any medals, but it represented West Papua province at the national level in 2018. In the Science Olympiad, it successfully represented West Papua province at the national level in Mathematics and Science in 2017 and 2018. Table 2 points a statistical summary of the pre-test's result.

Table 2

Pre-test's Results at the Preliminary Design

\begin{tabular}{cc}
\hline Total Students & $\mathbf{3 5}$ \\
\hline Mean & 9,74 \\
\hline Standard Deviation & 15,72 \\
\hline Median & 5 \\
\hline The Highest Score & 63 \\
\hline The Lowest Score & 0 \\
\hline Moderate Ability & 2 \\
\hline Low Ability & 33 \\
\hline
\end{tabular}

At the preliminary design, 35 students were finishing the problems representing mathematical thinking skills, and it referred to the characteristics of Matematika Nalaria Realistik as well as mathematics Olympiad problems (OSN and KSM), it indicated that all the students of the grade $\mathrm{V}$ found difficulties in solving the non-routine problems as well as indicators including in the mathematical thinking skills. The students are more likely often taught by their teacher on routine issues so that reasoning and problemsolving abilities of the students are still low. At the design experiment, the learning activities were conducted by applying the Matematika Nalaria Realistik learning model. Teaching activities were carried out six times a meeting. Teaching materials included basic algebra, natural number, fraction, and geometry. Each session not only applied the syntax of the MNR learning model but also it was given an exercise to solve the problems based on problem-solving and mathematical reasoning. The students were directed to be able to present their answer by paying attention to the indicators of mathematical communication skills as well as mathematical reasoning skills. Each 
students' response were analysed and then included in the students' progress book. At the seven meeting, it was evaluated post-test. Table 3 shows the results of the post-test.

Table 3

The Results of Post-test at the Design Experiment

\begin{tabular}{cc}
\hline Total Students & $\mathbf{3 5}$ \\
\hline Mean & 13,57 \\
\hline Standard Deviation & 13,75 \\
\hline Median & 10 \\
\hline The Highest Score & 77 \\
\hline The Lowest Score & 4 \\
\hline Good Ability & 1 \\
\hline Moderate Ability & 1 \\
\hline Low Ability & 33 \\
\hline
\end{tabular}

After the experimental learning model, data obtained from the learning activities in the classroom were analyzed retrospectively. Specifically, the purpose of the retrospective analysis stage was to evaluate the success of learning activities that have been conducted, observing students' learning progress, and informing learning activities progress. The retrospective analysis stage consists of data analysis, reflection, findings interpretation, and formulating the recommendations for future research.

The first step will be compared between the results of the pre-test and the results of the post-test, then it will be interpreted. Table 4 points the comparison of the result pre-test and post-test.

Table 4

Comparison of the Results Pre-Test and Post-test

\begin{tabular}{ccc}
\hline Criteria & Pre-test & Post-test \\
\hline Total Students & 35 & 35 \\
\hline Mean & 9,74 & 13,57 \\
\hline Standard Deviation & 15,72 & 13,75 \\
\hline Median & 5 & 10 \\
\hline The Highest Score & 63 & 77 \\
\hline The Lowest Score & 0 & 4 \\
\hline Good Ability & 0 & 1 \\
\hline Moderate Ability & 2 & 33 \\
\hline Low Ability & 33 &
\end{tabular}


Based on the learning activities applying the Matematika Nalaria Realistik, it was obtained that the MNR learning model has a positive contribution to grow and improve students' mathematical thinking skills. The average of students' thinking skills at the pre-test was 9,74 after being given intervention at the experiment design; the average increase at the post-test to 13,57 . Its increased percentage was $39,32 \%$. The standard deviation decreased from 15,72 to 13,75 . This finding showed that the smaller value of the standard deviation, then the impact of the intervention was far better.

\section{Local Instruction Theory}

Based on the results of the teaching experiment, then it was formed Local Instruction Theory to improve mathematical thinking skills by applying syntax of Matematika Nalaria Realistik on seven students. After conducting a pre-test, the students were given material enrichment in Mathematics Olympiad material (Algebra: integer, fraction, algebraic manipulation, number theory, geometry, problem-solving) designed based on the MNR's syntax. After teaching activities conducted three times meeting, a post-test was done to see the students' final progress, which was presented in table 5 .

Table 5

The Results of Post-test at LIT Stage

\begin{tabular}{ccc}
\hline Criteria & Pre-test & Post-test \\
\hline Total Students & 7 & 7 \\
\hline Mean & 38,29 & 72,28 \\
\hline Standard Deviation & 23,1 & 9,81 \\
\hline Median & 33 & 70 \\
\hline The Highest Score & 80 & 90 \\
\hline The Lowest Score & 15 & 62 \\
\hline Good Ability & 1 & 3 \\
\hline Moderate Ability & 1 & 4 \\
\hline Low Ability & 5 & 0 \\
\hline
\end{tabular}

The Local Instruction Theory designed has a significant result. This significant result was the improvement of students' mathematical thinking skills namely $88,77 \%$, on average of learning outcomes. The measured aspects are comprehension skills, 
communication skills, connection skills, and mathematical reasoning in algebraic problems, geometry, number theory, and problem-solving.

At the beginning of the teaching implementation in a small class consisting of 7 students, it was obtained five students with low ability, one student with moderate ability, and good ability, respectively. After teaching and math Olympiad tutoring using the MNR model, it was obtained satisfying results in which there was no student with low capacity, four students with moderate ability, and three students with good ability. This finding revealed that the success of the MNR model in selecting and finding students with unique skills and talented students in the math Olympiad.

The finding differs from the Nurmawati's research findings that did research increase in understanding of mathematical concepts with the MNR (Mathematical Realistic Mathematics) method in $8^{\text {th }}$ grade junior high school students. Nurmawati found that the MNR method did not improve the student's mathematical understanding. ${ }^{26}$ This distinction is possible because the Nurmawati's research procedures were problematic. Nurmawati's research has an unaccountable procedure, such as: dubious research validity, as seen in her article. Nurmawati did not present procedures operationally and clearly. In fact, Nurmawati still presented normative research procedures in her article.

This finding confirms the Palinussa which revealed that realistic mathematics education could improve student learning outcomes and critical thinking skills rather than classes that do not apply it. ${ }^{27}$ In addition to Palinnusa's research, this finding also strengthens the findings of Kurniati et al. research, which revealed that there was an increase in the mathematical critical thinking ability for students who received the Contextual Teaching Learning model. ${ }^{28}$ Thus, this study showed that learning with Matematika Nalaria Realistik model based on reasoning and contextual models can improve students' mathematical thinking skills.

${ }^{26}$ Restu Dian Nurmawati, "Peningkatan Pemahaman Konsep Matematika Siswa SMP Kelas 2 Melalui Metode MNR," Diskusi Panel Nasional Pendidikan Matematika 5, no. 1 (July 24, 2019), http://www.proceeding.unindra.ac.id/index.php/DPNPMunindra/article/view/230.

27 Anderson L. Palinussa, "Students' Critical Mathematical Thinking Skills and Character: Experiments for Junior High School Students through Realistic Mathematics Education Culture-Based," Indonesian Mathematical Society Journal on Mathematics Education 4, no. 1 (January 2013): 75-94, https://ejournal.unsri.ac.id/index.php/jme/article/download/566/161

${ }_{28}$ Kurniati et al., "Mathematical Critical Thinking Ability through Contextual Teaching and Learning Approach," Indonesian Mathematical Society Journal on Mathematics Education 6, no. 1 (January 2015): 53-62, https://ejournal.unsri.ac.id/index.php/jme/article/view/1901/0. 


\section{CONCLUSION}

The conclusions of this study were: (1) the successful of MNR learning model in the large class was 39,32\%; (2) Local Instruction Theory applied in the small class consisting of 7 students has more significant to improve students' mathematical skills namely $88,77 \%$; and (3) Implementation of MNR model was more reasonable for math Olympiad training with a small number of students namely less than ten students. MNR learning model for the selection of talented students in the Math Olympiad was recommended to be conducted in the small class with 5 to 10 students. For more optimum results, the implementation of the MNR teaching model was begun at $4^{\text {th }}$ grade students so that when they are in the $5^{\text {th }}$ grade, the students who have been trained in the material and MNR problems are better prepared for facing math competition mainly at the national level.

\section{REFERENCES}

Astari, E., and Marsigit. "Mathematical Connections Process for Elementary School Students in Problem Solving of Statistics." Journal of Physics: Conference Series 1280 (November 2019): 042008. https://doi.org/10.1088/17426596/1280/4/042008.

Ayunani, D. S., Mardiyana, and D. Indriati. "Analyzing Mathematical Connection Skill in Solving a Contextual Problem." Journal of Physics: Conference Series 1511 (April 2020): 012095. https://doi.org/10.1088/1742-6596/1511/1/012095.

Brown, Jessie, and Martin Kurzweil. Instructional Quality, Student Outcomes, and Institutional Finances. Washington, DC: American Council on Education, 2018. https://www.acenet.edu/Documents/Instructional-Quality-Student-Outcomesand-Institutional-Finances.pdf.

Director of Directorate of Primary and Secondary Education of MoEC. "Decree of the Directorate of Primary and Secondary Education of the Ministry of Education and Culture Regarding Data on Participants of the 2018 National Science Olympiad." the Directorate of Primary and Secondary Education of the Ministry of Education and Culture, 2018.

Directorate General of Primary and Secondary Education. Petunjuk Teknis Olimpiade Sains Nasional Sekolah Dasar Tahun 2018. Jakarta, Indonesia: Directorate General of Primary and Secondary Education Ministry of Education and Culture, 2018.

Gravemeijer, Koeno, and Dolly van Eerde. "Design Research as a Means for Building a Knowledge Base for Teachers and Teaching in Mathematics Education." The Elementary School Journal 109, no. 5 (May 1, 2009): 510-24. https://doi.org/10.1086/596999. 
Isoda, Masami, and Shigeo Katagiri. Mathematical Thingking: How to Develop It in the Classroom. Singapore: World Scientific, 2012.

Kurniati, Yaya S. Kusumah, Jozua Sabandar, and Tatang Herman. "Mathematical Critical Thinking Ability through Contextual Teaching and Learning Approach." Indonesian Mathematical Society Journal on Mathematics Education 6, no. 1 (January 2015):

$53-62$, https://ejournal.unsri.ac.id/index.php/jme/article/view/1901/0.

National Council of Teachers of Mathematics (NCTM). Principles and Standards for School Mathematics. Reston: NTCM, 2000.

Nurmawati, Restu Dian. "Peningkatan Pemahaman Konsep Matematika Siswa SMP Kelas 2 Melalui Metode MNR." Diskusi Panel Nasional Pendidikan Matematika 5, no. 1 (July 24, http://www.proceeding.unindra.ac.id/index.php/DPNPMunindra/article/view/23 0 .

Palinussa, Anderson L. "Students' Critical Mathematical Thinking Skills and Character: Experiments for Junior High School Students through Realistic Mathematics Education Culture-Based." Indonesian Mathematical Society Journal on Mathematics Education 4, no. 1 (January 2013): 75-94, https://ejournal.unsri.ac.id/index.php/jme/article/download/566/161.

Polya, G. How to Solve It: A New Aspect of Mathematical Method. Garden City, New York: Doubleday \& Company Inc., 1985. https://math.hawaii.edu/home/pdf/putnam/PolyaHowToSolveIt.pdf.

Prahmana, Rully C.I. Design Research (Teori Dan Implementasinya: Suatu Pengantar). Depok: Rajawali Perss, 2017.

Prastowo, Andi, Mujadi Mujadi, Purnaida Purnaida, and Bayu Rahmad Santosa. "Pembelajaran Keterampilan Berpikir Kritis: Studi Kasus Di MIM Ngipik Dan MIM Dondong Kulonprogo.” Edukasia : Jurnal Penelitian Pendidikan Islam 13, no. 2 (May 27, 2019): 305-28. https://doi.org/10.21043/edukasia.v13i2.3525.

Ratnasari, G. I., and A. M. Abadi. "Investigating Mathematical Literacy, Mathematical Reasoning Skill, and Self Esteem of a Public High School." Journal of Physics: Conference Series $1097 \quad$ (September 2018): 012096. https://doi.org/10.1088/1742-6596/1097/1/012096.

Rosdianwinata, E., R. Rifa'i, and Anton Nasrullah. "Implementation of Peer Tutor Learning in Improving Students' Mathematical Understanding Ability." Journal of Physics: Conference Series 1315 (October 2019): 012027. https://doi.org/10.1088/1742-6596/1315/1/012027.

Rusdin, Rusdin. "Meningkatkan Kemampuan Berpikir Matematis Siswa Melalui Model Pembelajaran Matematika Nalaria Realistik Pada Madrasah Ibtidaiyah Di Kota Sorong." Al-Riwayah: Jurnal Kependidikan 11, no. 2 (September 2, 2019): 283-96, https://e-jurnal.iainsorong.ac.id/index.php/AlRiwayah/article/download/196/193.

Sarkam, I. Sujadi, and S. Subanti. "Mathematical Connections Ability in Solving Trigonometry Problems Based on Logical-Mathematical Intelligence Level." 
Journal of Physics: Conference Series 1188 (March 2019): 012022. https://doi.org/10.1088/1742-6596/1188/1/012022.

Stacey, Kaye. What Is Mathematical Thinking and Why Is It Important? Melbourne: University of Melbourne, 2006.

. "What Is Mathematical Thinking and Why Is It Important." Accessed May 19, 2020.

https://www.academia.edu/34010244/What_is_mathematical_thinking_and_why _is_it_important.

Susanti, E., and Hartono. "An Analysis Mathematical Problem Solving and Mathematical Critical Thinking Skills of Junior High School Students." Journal of Physics: Conference Series 1320 (October 2019): 012071. https://doi.org/10.1088/1742-6596/1320/1/012071.

Van de Walle, John A., and Jennifer M. Bay-Williams. Elementary and Middle School Mathematics: Teaching Developmentally (7th Edition). USA: Pearson Education, 2010.

Vega Rinata, Mela. "Penerapan Metode Matematika Nalaria Realistik Di Klinik Pendidikan MIPA Cabang 1 Surabaya." Jurnal Penelitian Pendidikan Guru Sekolah Dasar 7, no. 1 (January 24, 2019). https://jurnalmahasiswa.unesa.ac.id/index.php/jurnal-penelitianpgsd/article/view/26884.

Website Manager of MoEC. "Tingkatkan Mutu Pendidikan Melalui 4 Hal Ini." Kementerian Pendidikan dan Kebudayaan, August 17, 2018. https://www.kemdikbud.go.id/main/blog/2018/08/tingkatkan-mutu-pendidikanmelalui-empat-hal-ini.

Wulandari, S. Y., and D. U. Wutsqa. "A Study of Junior High School Students Reasoning Skill in Mathematics." Journal of Physics: Conference Series 1320 (October 2019): 012059. https://doi.org/10.1088/1742-6596/1320/1/012059.

Yaman, N. A. P., and Jailani. "The Effect of Changes in Mathematics Curriculum in Improving Students' Reasoning Skills and Mathematical Problem Solving." Journal of Physics: Conference Series 1320 (October 2019): 012108. https://doi.org/10.1088/1742-6596/1320/1/012108. 